Металлофиз. новейшие технол. / Metallofiz. Noveishie Tekhnol. () 2015 ИМФ (Институт металлофизики 2015, т. 37, № 8, сс. 1017-1026

Оттиски доступны непосредственно от издателя

им. Г. В. Курдюмова НАН Украины)

Фотокопирование разрешено только

Напечатано в Украине.

в соответствии с лицензией

PACS numbers: 61.05.cc, 61.05.cf, 61.72.Dd, 61.72.up, 61.80.Jh, 61.82.Ms, 68.55.Ln

\title{
Quantum-Mechanical Model of Interconsistent Amplitude and Dispersion Influences of Structure Imperfections on the Multiple- Scattering Pattern for Mapping and Characterization of Strains and Defects in Ion-Implanted Garnet Films
}

\author{
V. B. Molodkin, S. I. Olikhovskii, E. S. Skakunova, E. G. Len, \\ E. N. Kislovskii, O. V. Reshetnyk, T. P. Vladimirova, V. V. Lizunov, \\ L. N. Skapa, S. V. Lizunova, E. V. Fuzik, N. G. Tolmachev, \\ B. K. Ostafiychuk*, V. M. Pylypiv", and O. Z. Garpul'*
}

G.V.Kurdyumov Institute for Metal Physics, N.A.S. of Ukraine, 36 Academician Vernadsky Blvd.,

UA-03680 Kyiv, Ukraine

"Vasyl Stefanyk Precarpathian National University,

57 Shevchenko Str.,

UA-76025 Ivano-Frankivsk, Ukraine

Numerical simulation of the reciprocal-space maps for ion-implanted singlecrystal yttrium-iron garnet films on gadolinium-gallium garnet substrates is carried out and based on the theoretical model of the triple-axes dynamical diffractometry of multilayer crystalline systems with inhomogeneous strain distributions and randomly distributed defects. In this model, the amplitude and dispersion mechanisms of influence of the structure imperfections on diffraction or refraction, absorption and extinction of radiation, respectively, for the coherent and diffuse scattering intensities are interconsistently taken into account for all the layers of the system, using derived recurrent relations between the coherent-scattering amplitudes. The presence of growth defects in both the film and the substrate as well as radiation defects created in subsurface layer of nanometre-scale thickness after $90 \mathrm{keV} \mathrm{F}^{+}$ion implantation are taken into account in the proposed model of the multilayer systems. Using this model, the rocking curves measured from as-grown and ion-implanted samples are also treated for determination of realistic strain-profile parameters and structural-defect characteristics in both implanted films and substrates with the aim of numerical reconstruction of the diffraction patterns from multilayer imperfect single-crystal systems.

Чисельне моделювання карт оберненого простору для йонно-імплантованих монокристалічних залізо-ітрійових плівок ферит-гранатів на підложжях з ґадоліній-ґалійового гранату здійснено на основі теоретичного 
моделю тривісної динамічної дифрактометрії для багатошарових кристалічних систем із неоднорідними розподілами деформації та випадково розподіленими дефектами. В цьому моделі амплітудний і дисперсійний механізми впливу недосконалостей структури відповідно на дифракцію чи на заломлення, поглинання й екстинкцію випромінення в інтенсивності когерентного та дифузного розсіяння взаємоузгоджено враховувалися для всіх шарів системи за допомогою одержаних рекурентних співвідношень між амплітудами когерентного розсіяння. В запропонованому моделі багатошарових систем враховано наявність ростових дефектів, як у плівці, так і в підложжі, а також радіяційних дефектів у приповерхневому шарі нанометрової товщини, утворених після імплантації йонів $\mathrm{F}^{+}$з енергією у 90 кеВ. 3 використанням зазначеного моделю також оброблялися криві хитання вихідного та йонно-імплантованого зразків для визначення реалістичних параметрів профілів деформації та структурних характеристик дефектів у підложжях та імплантованих плівках з метою чисельної реконструкції картин динамічної дифракції від монокристалічних багатошарових зразків.

Численное моделирование карт обратного пространства для ионноимплантированных монокристаллических железо-иттриевых плёнок феррит-гранатов на подложках из гадолиний-галлиевого граната осуществлено на основе теоретической модели трёхосной динамической дифрактометрии для многослойных кристаллических систем с неоднородными распределениями деформации и случайно распределёнными дефектами. В этой модели амплитудный и дисперсионный механизмы влияния несовершенств структуры соответственно на дифракцию или на преломление, поглощение и экстинкцию излучений в интенсивности когерентного и диффузного рассеяния взаимосогласованно учитывались для всех слоёв системы с помощью полученных рекуррентных соотношений между амплитудами когерентного рассеяния. В предлагаемой модели многослойных систем учтено наличие ростовых дефектов, как в плёнке, так и в подложке, а также радиационных дефектов в приповерхностном слое нанометровой толщины, образованных после имплантации ионов $\mathrm{F}^{+}$с энергией 90 кэВ. С использованием упомянутой модели также обрабатывались кривые качания исходного и ионно-имплантированного образцов для реалистичного определения параметров профилей деформации и структурных характеристик дефектов в подложках и имплантированных плёнках с целью численной реконструкции картин динамической дифракции от монокристаллических многослойных образцов.

Key words: dynamical diffraction theory, thin films, yttrium-iron garnet, ion implantation, radiation defects, strain distribution, growth defects.

(Received May 17, 2015)

\section{INTRODUCTION}

Modern technologies allow to grow almost perfect multilayer crystalline systems and to influence purposefully on their physical properties by the controlled introduction of various structural defects. In partic- 
ular, epitaxial single-crystal yttrium-iron garnet (YIG) $\mathrm{Y}_{3} \mathrm{Fe}_{5} \mathrm{O}_{12}$ films grown on gadolinium-gallium garnet (GGG) $\mathrm{Gd}_{3} \mathrm{Ga}_{5} \mathrm{O}_{12}$ substrate are widely used in energy-independent magnetic-memory devices, magnetic microelectronics, and integral magnetooptics, etc. (see, e.g., Ref. [1]). Modification of physical properties of their functional layers with sizes, which are often of nanometre scale, is carried out, in particular, by ion implantation.

X-ray diffraction methods are most widely used to characterize structural defects and strains in the modified crystal layers. In particular, the measurements by high-resolution double-crystal diffractometer (DCD) and triple-crystal one (TCD) were carried out to characterize inhomogeneous strain distributions and structure imperfections in implanted garnet crystals [2, 3]. These methods are highly informative if the analytical formulae, which give the adequate description of measured diffraction-intensity distributions, are available and used in interconsistent combination for both components of intensity (i.e., for Bragg and diffuse scattering) and different dynamical diffraction conditions or measurements methods (i.e., commonly integral, DCD, and TCD diffractometry).

The purpose of this work is demonstration of diagnostic possibilities offered by the theoretical method for interpretation of results of highresolution X-ray diffraction mapping of the real film and multilayer systems with defects [4]. This method of structural diagnostics will be applied to the simulation of the influence of nanometre-size defects and inhomogeneous strain distributions in the epitaxial YIG films grown on GGG substrate, which were implanted with $90 \mathrm{keV} \mathrm{F}^{+}$ions, on the form of the coherent and diffuse components of diffraction intensity distributions on reciprocal-lattice maps measured by TCD.

\section{COHERENT AND DIFFUSE COMPONENTS OF RECIPROCAL- LATTICE MAPS}

Differential X-ray diffraction intensity distributions measured by TCD from multilayer crystalline systems with inhomogeneous strain distributions and randomly distributed defects can be represented as a sum of coherent $\left(I_{\text {coh }}\right)$ and diffuse $\left(I_{\text {diff }}\right)$ components.

If Bragg angles for monochromator, analyser, and crystal under investigation are nearly equal, it is possible to ignore the dispersion effects and the coherent component of the two-dimensional intensity distribution can be calculated approximately in the case of quasinondispersive geometry $(m,-n, m)$ as follows $[5,6]$ :

$$
I_{\text {coh }}\left(\Delta \theta, \Delta \theta^{\prime}\right) \cong I_{0} b_{\mathrm{S}} \int_{-x_{\mathrm{m}}}^{x_{\mathrm{m}}} d z R_{\mathrm{M}}\left(b_{\mathrm{M}}^{-1} z\right) R_{\mathrm{coh}}(z+\Delta \theta) R_{\mathrm{A}}\left[b_{\mathrm{S}} z+\Delta \theta\left(1+b_{\mathrm{S}}\right)-\Delta \theta^{\prime}\right]
$$


where $I_{0}$ is an intensity of incident X-ray beam, $R_{\mathrm{M}}$ and $R_{\mathrm{A}}$ are the reflection coefficients of monochromator and analyser crystals, $\Delta \theta$ and $\Delta \theta^{\prime}$ are the angular deviations of the crystal under investigation and analyser crystal, $b_{\mathrm{M}}$ and $b_{\mathrm{S}}$ are asymmetry parameters of monochromator and sample crystals, respectively. The expression for the coherent component of the reflection coefficient $R_{\text {coh }}(\Delta \theta)$ for imperfect crystal has been derived elsewhere earlier [7] and takes into account all the dynamical scattering effects including the extinction of Bragg waves due to diffuse scattering by defects as well as dispersion mechanism of influence of a sample structure on multiple-scattering pattern.

Particularly, the dynamical consideration is necessary in the case of X-ray diffraction by the implanted YIG films of thickness, which is of the order of an extinction length. The coherent component of reflection coefficient of such inhomogeneous crystalline system with chaotically distributed defects can be calculated in so called 'layer approximation' using the recurrence relations between coherent components of amplitude reflection coefficients of adjacent layers for Bragg diffraction geometry [5]:

$$
R_{j}=\frac{r_{j}+R_{j-1}\left(e_{j}^{-1} t_{j}^{2}-\zeta_{j}^{-1} r_{j}^{2}\right)}{1-\zeta_{j}^{-1} r_{j} R_{j-1}},
$$

where $r_{j}$ and $t_{j}$ are amplitudes of reflectivity and transmissivity of $j^{\text {th }}$ layer, respectively, $e_{j}$ is the phase factor, and $\zeta_{j} \cong 1$.

The diffuse component of the diffraction intensity measured by TCD can be represented approximately by the following expression $[5,6]$ :

$$
I_{\text {diff }}\left(\Delta \theta, \Delta \theta^{\prime}\right) \cong I_{0} R_{\text {iM }} R_{\text {iA }} r_{\text {diff }}(\mathbf{k}),
$$

where $R_{\mathrm{im}}$ and $R_{\mathrm{iA}}$ are the integrated reflectivities of monochromator and analyser crystals, respectively, and components $k_{x}$ and $k_{z}$ of twodimensional vector $\mathbf{k}$ describe a deviation from the reciprocal-lattice point $\mathbf{H}$ in the coherent-scattering plane.

Function $r_{\text {diff }}(\mathbf{k})$ in Eq. (3) represents the diffuse component of the differential reflection coefficient of the multilayer sample (containing $M$ layers) after integration over vertical divergence [7]:

$$
r_{\text {diff }}(\mathbf{k})=\sum_{j=0}^{M} F_{\text {ext }}^{j} F_{\text {abs }}^{j} r_{\text {diff }}^{j}(\mathbf{k}),
$$

where $F_{\text {ext }}^{j}$ is the extinction factor describing the influence of redistribution of X-ray intensity between the transmitted and diffracted coherent waves in $j^{\text {th }}$ layer, the factor $F_{\text {abs }}^{j}$ describes photoelectric absorption and absorption caused by diffuse scattering in layers lying above $j^{\text {th }}$ layer, and $r_{\text {diff }}^{j}(\mathbf{k})$ is the diffuse component of the differential reflection coefficient of $j^{\text {th }}$ layer. 
Thus, the formulae presented above provide the possibilities for the effective, i.e., with minimization of required calculation time expenses, and self-consistent quantitative analysis of the coherent and diffuse components of reciprocal-lattice maps, which are measured from crystalline film or multilayer systems, including those with inhomogeneous strain distributions, large strain gradients at layer interfaces, and randomly distributed defects of different types in all the layers and substrate.

\section{MODEL OF THE DEFECT STRUCTURE IN ION-IMPLANTED YIG FILM}

The sample of the epitaxial YIG film with $5.33 \mu \mathrm{m}$ thickness, which was grown on GGG substrate and implanted with $\mathrm{F}^{+}$ions of the $90 \mathrm{keV}$ energy at dose $D=6 \cdot 10^{13} \mathrm{~cm}^{-2}$, has been chosen as a model object for simulation.

To determine realistic strain-profiles' parameters and structuraldefects' characteristics, this sample was investigated using the highresolution double-crystal X-ray diffractometer (see, for example, Fig. 1). As has been established by simultaneous treatment of the rocking curves (RC) measured for symmetric (444) and (888) reflections, the strain profile in YIG film implanted with $\mathrm{F}^{+}$ions has the shape shown

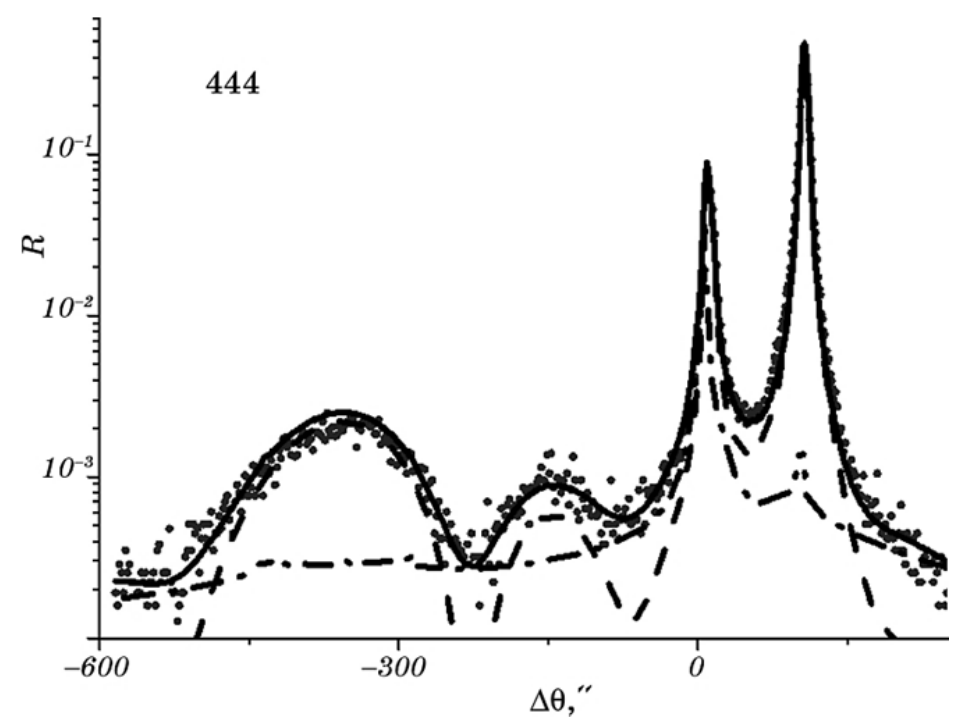

Fig. 1. Measured (markers) and calculated (solid line) RCs for (444) reflection of $\mathrm{CuK} K_{\alpha 1}$-radiation from YIG/GGG film system implanted with $\mathrm{F}^{+}$ions $(E=90 \mathrm{keV})$ at doses $D=6 \cdot 10^{13} \mathrm{~cm}^{-2}$. The coherent and diffuse RC components are shown by dashed and dot-dashed lines, respectively. 


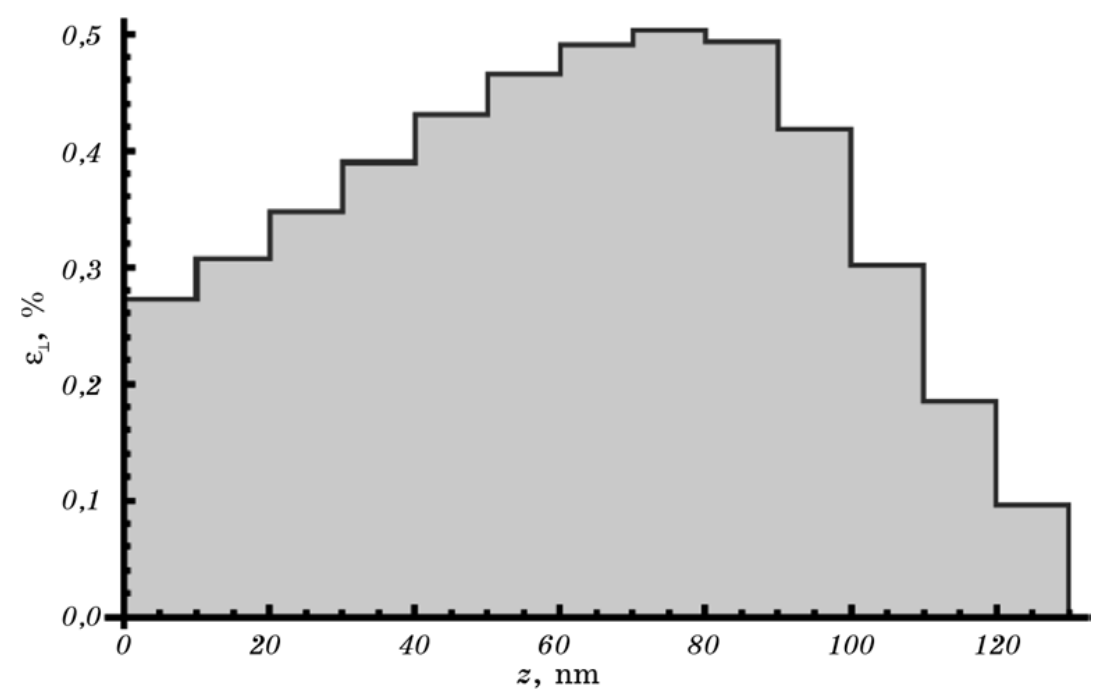

Fig. 2. Strain profile in YIG film implanted with $\mathrm{F}^{+}$ions $(E=90 \mathrm{keV})$ at dose $D=6 \cdot 10^{13} \mathrm{~cm}^{-2}$.

in Fig. 2. This strain profile is formed due to the radiation defects, which are distributed inhomogeneously in depth and cause the corresponding 'in average' inhomogeneous strain. The depth profile of the strain caused by ion implantation is calculated, using the determined characteristics of spherical amorphous clusters in implanted layer, namely, concentration of $5 \cdot 10^{20} \mathrm{~cm}^{-3}$, radius of $0.75 \mathrm{~nm}$, and volume misfit strain at the boundary between cluster and crystal matrix $\cong 0.0375$.

Besides, in the model of defect structure of the implanted epitaxial single-crystalline system of YIG film grown on GGG substrate, the presence of two types of growth microdefects, namely, spherical clusters and circular prismatic dislocation loops is taken into account. Their characteristics are also determined by the DCD-profiles' treatment; namely, for spherical clusters in YIG film and GGG substrate, we put cluster radii of 10 and $8 \mathrm{~nm}$, respectively, concentration of $10^{14} \mathrm{~cm}^{-3}$, and volume misfit strain at the boundary between cluster and crystal matrix of $\mathbf{0 . 0 3}$. Similarly, for dislocation loops of $<\mathbf{1 1 0}>$ type within the YIG film, we put dislocation loop radius of $5 \mathrm{~nm}$ and concentration of $10^{15} \mathrm{~cm}^{-3}$, whereas, within the GGG substrate, we put dislocation loop radii of 5 and $90 \mathrm{~nm}$, and concentrations of $10^{15}$ and $1,2 \cdot 10^{12} \mathrm{~cm}^{-3}$, respectively.

The YIG/GGG film system as a whole is considered as a multilayer system in each layer of which the strain is consisted of sum of average and fluctuating components. At modelling, the average strain distribution, the implanted layer is subdivided into $10 \mathrm{~nm}$ thick laminae, 
whereas the transition layer between film and substrate is subdivided into layers with thicknesses of order of few hundreds of nanometres.

\section{SIMULATION OF RECIPROCAL-LATTICE MAPS FOR ION-IMPLANTED YIG FILMS WITH DEFECTS}

The results of numeral simulation of reciprocal-lattice maps are described below for the YIG film, which was implanted with $\mathrm{F}^{+}$ions of the energy of $90 \mathrm{keV}$ at dose $D=6 \cdot 10^{13} \mathrm{~cm}^{-2}$. The maps were simulated for the case of measurements by the high-resolution PANalytical X'Pert Pro MRD XL diffractometer for (444) reflection of characteristic $\mathrm{Cu} K_{\alpha 1}$-radiation in the symmetrical Bragg diffraction geometry at the sample under investigation. As far as the Bragg angle for Ge (220) reflection used in monochromator and analyser crystals of the diffractometer is nearly equal to Bragg angles for (444) reflection of YIG film and GGG substrate, the influence of dispersion effects can be neglected, and for calculation of the coherent and diffuse components of reciprocal-lattice maps, the simplified formulae (1) and (3) can be used.

To elucidate the role of microdefects growth in YIG film and GGG substrate in the formation of diffraction patterns, we first calculated the reciprocal-lattice map for the symmetrical (444) reflection of $\mathrm{Cu} K_{\alpha 1}$-radiation from as-grown YIG/GGG film system (Fig. 3). As is
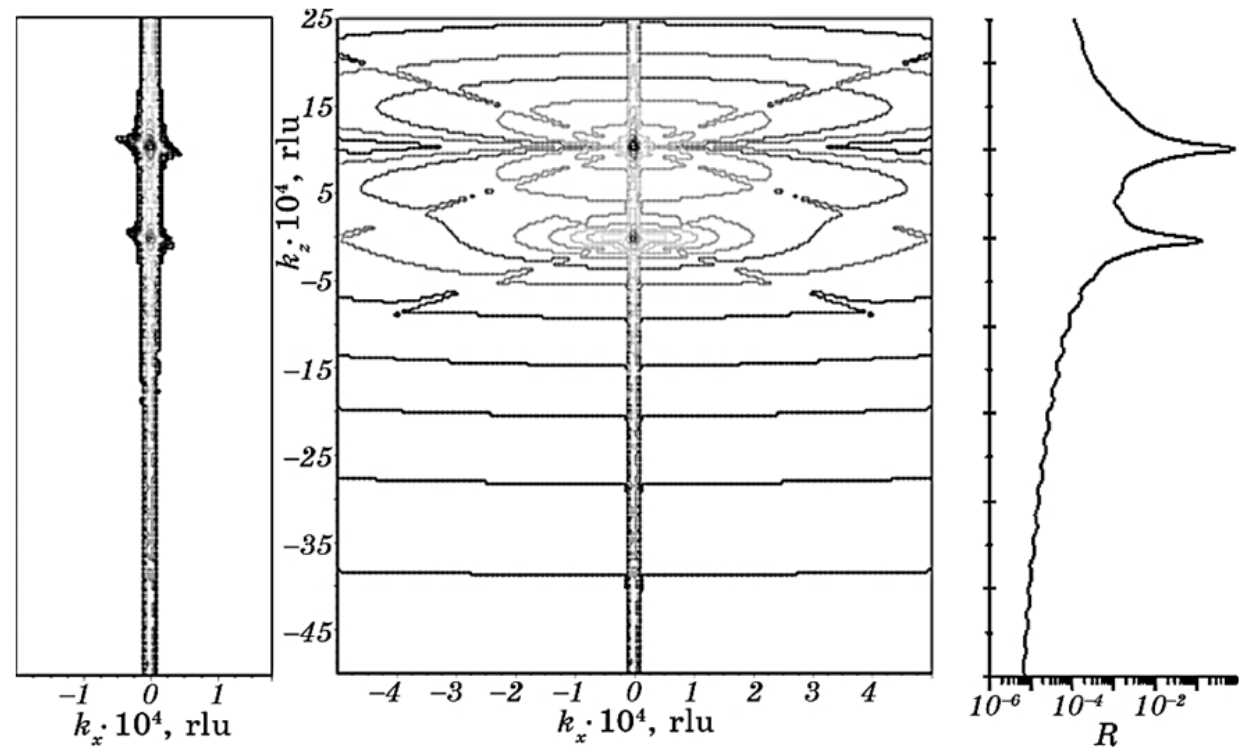

Fig. 3. Reciprocal-lattice map (middle), its coherent component (left), and longitudinal cross section (right) for (444) reflection of $\mathrm{Cu} K_{\alpha 1}$-radiation from as-grown YIG/GGG film system. 
evident from comparison between the total reciprocal-lattice map and its coherent component, the diffuse scattering intensity from microdefects in both the YIG film and the GGG substrate give a substantial contribution to the formation of observed diffraction-intensity distributions.

The reciprocal-lattice map simulated for the symmetrical (444) reflection of $\mathrm{Cu} K_{\alpha 1}$-radiation from the YIG/GGG film system implanted with $\mathrm{F}^{+}$ions of $90 \mathrm{keV}$ energy at dose $D=6 \cdot 10^{13} \mathrm{~cm}^{-2}$ is shown in Fig. 4 .

As can be seen by comparing Figs. 3 and 4, the irregularly shaped diffuse scattering intensity distribution from spherical clusters in implanted YIG layer appears additionally to the diffuse scattering intensity distributions from microdefects in both YIG film and GGG substrate around corresponding reciprocal-lattice points. It should be noted that the irregular shape of diffuse scattering intensity distribution from spherical clusters in implanted layer is caused by the inhomogeneous 'in-average' strain distribution in this layer, which leads to smoothing and deformation of the double-drop form known for isodiffuse lines from spherical clusters.

It should be especially emphasized that longitudinal cross sections of the simulated reciprocal-lattice maps in Figs. 3 and 4 closely coincide in form with the rocking curves, which were measured using the high-resolution double-crystal X-ray diffractometer for the corre-


Fig. 4. Reciprocal-lattice map (middle), its coherent component (left), and longitudinal cross section (right) for (444) reflection of $\mathrm{CuK} K_{\alpha 1}$-radiation from YIG/GGG film system implanted with $\mathrm{F}^{+}$ions $(E=90 \mathrm{keV})$ at dose $D=6 \cdot 10^{13} \mathrm{~cm}^{-2}$. 
sponding as-grown and implanted epitaxial YIG films (Fig. 1). The only distinction consists in that the oscillations at the tail of the rocking curve measured from implanted epitaxial YIG film are something smoothed as compared with longitudinal cross section of the simulated reciprocal-lattice map in Fig. 4, which is explained by an additional contribution of diffuse scattering intensity from defects in implanted YIG layer due to integration over vertical divergence.

\section{RESUME AND CONCLUSIONS}

On the basis of the created theoretical model of the triple-crystal X-ray dynamical diffractometry of the multilayer crystalline systems with inhomogeneous strain profile and randomly distributed defects, the numerical simulation of reciprocal-lattice maps for the ion-implanted single-crystal YIG films on GGG substrate has been carried out. The presence of growth defects in both the film and the substrate as well as radiation defects created in subsurface layer are taken into account.

It is established that, as a result of superposition of coherent and diffuse-scattering intensities from defects of various types in different layers with heterogeneous strain, the reciprocal-lattice maps take the form, which substantially differs from that characteristic for crystals with homogeneous strain and one type of defects.

Self-consistent description of the coherent and diffuse components of dynamical X-ray scattering with account for amplitude and dispersion mechanisms of influence of structure imperfections on multiplescattering pattern as well as instrumental factors of TCD makes possible the correct quantitative analysis of complete reciprocal-lattice maps measured from inhomogeneous imperfect crystal structures with defects.

\section{REFERENCES}

1. T. Wehlus, T. Körner, S. Leitenmeier, A. Heinrich, and B. Stritzker, phys. status solidi (a), 208: 252 (2011).

2. B. K. Ostafiychuk, I. P. Yaremiy, S. I. Yaremiy, V. D. Fedoriv, U. O. Tomyn, M. M. Umantsiva, I. M. Fodchuk, and V. P. Kladko, Crystallography Reports, 58: 1017 (2013).

3. I. M. Fodchuk, V. V. Dovganiuk, I. I. Gutsuliak, I. P. Yaremiy, A. Y. Bonchyk, G. V. Savytsky, I. M. Syvorotka, and O. S. Skakunova, Metallofiz. Noveishie Tekhnol., 35, No. 9: 1209 (2013) (in Russian).

4. O. S. Skakunova, S. I. Olikhovskii, V. B. Molodkin, E. G. Len, E. M. Kislovskii, O. V. Reshetnyk, T. P. Vladimirova, E. V. Kochelab, V. V. Lizunov, S. V. Lizunova, V. L. Makivs'ka, M. G. Tolmachov, L. M. Skapa, Ya. V. Vasylyk, and K. V. Fuzik, Metallofiz. Noveishie Tekhnol., 37: No. 3: 409 (2015) (in Ukrainian). 
5. V. B. Molodkin, S. I. Olikhovskii, E. G. Len, E. N. Kislovskii, V. P. Kladko, O. V. Reshetnyk, T. P. Vladimirova, and B. V. Sheludchenko, phys. status solidi (a), 206: 1761 (2009).

6. E. N. Kislovskii, V. B. Molodkin, S. I. Olikhovskii, E. G. Len, B. V. Sheludchenko, S. V. Lizunova, T. P. Vladimirova, E. V. Kochelab, O. V. Reshetnik, V. V. Dovganyuk, I. M. Fodchuk, T. V. Litvinchuk, and V. P. Klad'ko, J. Surf. Investigation. X-Ray, Synchrotron, and Neutron Techniques, 7: 523 (2013).

7. V. B. Molodkin, S. I. Olikhovskii, Ye. M. Kyslovskyy, I. M. Fodchuk, E. S. Skakunova, E. V. Pervak, and V. V. Molodkin, phys. status solidi (a), 204: 2606 (2007). 